УДК 340.1

DOI https://doi.org/10.32849/2663-5313/2020.4.42

олег Савчук,

канд. філос. наук,

завідувач кафедри богослов'я та суспільствознавчих дисщиплін

Української академії наук імені академіка Івана Луцького

ПВНЗ «Університет Короля Данила»

\title{
Оксана Каленюк,
}

канд. юрид. наук,

дочент кафедри теорії та історії держави і права

ПВНЗ «Університет Короля Данила»

\section{ПРОЦЕС ЮРИДИЧНОГО ЗАКРІПЛЕННЯ ПРАВ I СВОБОД ЛЮДИНИ І ГРОМАДЯНИНА В УКРАЇНІ: МІЖНАРОДНО-ПРАВОВИЙ ДОСВІД}

У статті аналізується прочес становлення та розвитку міжнародно-правової співпращі між Україною та ЄС. Головний акцент робиться на пошуку оптимальних шляхів гармонізаиії українського законодавства із законодавством ЄС у сфері забезпечення прав і свобод людини і громадянина. Доведено, що євроінтеграчія передбачає проведення складних внутрішніх реформ у політичній, соиіальній, економічній та правовій сферах, здійснення яких регламентується поетапно Угодою про асоиіацію між Україною та ЄС як чентральним документом у ивому сегменті політично-правових перетворень. Особливо вагомим у ивому контексті є аксіологічний складник, завдяки якому функиіонують інтеграчійні та кореляційні механізми узгодження норм украйнського та міжнародного права. Визначено, що ефективність норм міжнародного права та ступінь їх ідеологічної гнучкості, що уможливлює здатність адаптації до вітчизняного законодавства, на наш погляд, залежить від реального, повного та всебічного використання суб'єктами, наділеними можливостями, їх потениіалу. Наголошено, що основним методом узгодження начіонального законодавства України із законодавством Євросоюзу є непряма гармонізачія, тобто прийняття законодавчих актів має відбуватися поетапно, насамперед з урахуванням інтересів нашої держави. Зроблено висновок, що адаптація чинного українського законодавства до законодавства $Є C$ - обов'язковий чинник успішної реалізаціі європейських прагнень України. Розуління важливості та складності ивого проиесу, конструктивна співпраия всіх гілок влади, вдале застосування підходів та методів до багатогранності європейського правового поля, а також урахування досвіду асоиійованих крайн ЕС дасть позитивний результат. Європейська інтеграція передбачає чілеспрямоване здійснення урядом та парламентом України чілої низки кроків щодо впровадження європейських стандартів в усіх сферах суспільного $і$ державного життя. Нинішній стан євроінтеграчійних процесів вимагає не тільки чітких, але й більш енергійних кроків керівниитвом української держави, які пов'язані пери за все з ефективним проведенням реформ в Украйні не в далекій чи ближній перспективі, а вже сьогодні і негайно.

Ключові слова: міжнародні правові норми, права і свободи людини, імплементація правових норм, конституційні норми правового регулювання.

Актуальність теми. Свропейський Союз на власному прикладі демонструє важливість взаємодії громадянського суспільства з органами влади. За рахунок розвитку правової держави можливе функціонування повноцінного громадянського суспільства. Вступ України до $\mathrm{CC} \mathrm{дасть} \mathrm{змогу} \mathrm{просунутися} \mathrm{українському}$ суспільству на наступний щабель у напрямі до утвердження європейських цінностей функціонування громадянського суспільства, а саме: розвиток та реалізація правової держави можливі за рахунок реструктуризації законодавства, виконання якого має бути обов'язковим для всіх; захисту порушених прав та свобод людини i громадянина; подолання корупційних процесів відповідно до міжнародних визнаних норм. Свросоюз пропагує у своїй зовнішній політиці просування відповідних цінностей у сфері зміцнення громадянського суспільства, що і виступає одним із важливих завдань на шляху до членства в ньому.

Мета цієї розвідки - показати історичноправову еволюцію українського законодавства в контексті євроатлантичних прагнень України. 
Для досягнення поставленої мети необхідно вирішити такі дослідницькі завдання:

- розкрити головні етапи становлення правової співпраці між Україною та $\mathrm{CC}$;

- проаналізувати процес юридичного закріплення прав і свобод людини в контексті євроінтеграції;

- охарактеризувати перспективи і тенденції розвитку міжнародно-правової співпраці між Україною та СС.

Об'єктом дослідження є правова взаємодія між Україною та СС.

Предметом дослідження $€$ міжнародноправовий контекст формування законодавчої бази України щодо історичного та юридичного становлення і забезпечення прав і свобод людини і громадянина.

Виклад основного матеріалу. Проблема імплементації міжнародних норм у процесі реалізації ідеологічної функції сучасного українського права в контексті ефективності міжнародного права і його норм висувається на одне 3 перших місць у доктрині і в практиці міжнародно-правового регулювання.

Зростання значення і ролі міжнародноправового регулювання визначається передусім таким об'єктивним чинником, як зростаюча взаємозалежність між народами. Сучасний світ стає усе більш цілісним, інтегрованим і потребує впорядкованої поведінки держав. Це можливо забезпечити передусім за допомогою соціальних норм, серед яких міжнародному праву належить важливе місце.

Реалізація норм міжнародного права $\epsilon$ складним процесом, що поступово імплементується у вітчизняну правову реальність 3 її ще не до кінця сформованими ідеологічно-правовими установками. У цьому процесі беруть участь не лише сторони, що є носіями суб'єктивних прав і обов'язків, але і держава в особі різних органів законодавчої, виконавчої, судової влади. Реалізація норм міжнародного права $€$ процесом активної і пасивної діяльності його суб'єктів [8, с. 12].

Виходячи 3 цього, ефективність норм міжнародного права та ступінь ї ідеологічної гнучкості, що уможливлює здатність адаптації до вітчизняного законодавства, на наш погляд, залежить від реального, повного та всебічного використання суб'єктами, наділеними можливостями, їх потенціалу. Поведінка суб'єктів міжнародного права на міжнародній арені визначається різними показниками. На поведінку суб'єктів міжнародного права, окрім права, чинять також вплив інші соціальні регулятори, чинники, що характеризують поведінку суб'єктів, самі по собі не визначають ефективність міжнародно-правового акта, проте вони є важли- вими умовами, що впливають на досягнення ефективності в процесі практичної діяльності з реалізації правових норм.

Отже, солідаризуємось зі слушною думкою Л. Луця про те, що ефективність правової інтеграції багато в чому залежить від заходів і способів, які використовуються державами на різних стадіях цього складного та багаторівневого процесу. До них вона відносить, зокрема, створення демократичних засад розвитку суспільства, формування правової держави, реформування інституційної та нормативної частин правової системи суспільства, формування правової свідомості населення відповідно до основних засад європейського права [6, с. 55].

Україна взяла на себе названі зобов'язання з урахуванням того, що їх реалізація шляхом трансформації й адаптації регулятивної функції права сприятиме прискоренню ринкових реформ, а також сприятиме розширенню зони вільної торгівлі між Україною та Європейським Союзом. На нашу думку, основним методом узгодження національного законодавства України із законодавством Євросоюзу є непряма гармонізація, тобто прийняття законодавчих актів має відбуватися поетапно, насамперед 3 урахуванням інтересів нашої держави. Норми та принципи законодавчих актів Євросоюзу мають ураховуватися в межах доцільності для України з огляду на економічні, політичні та соціальні наслідки прийняття узгоджених 3 європейськими стандартами законодавчих актів. Така діяльність має проводитись у відповідності до особливостей соціально-економічної та суспільно-політичної ситуації.

Для ефективності правового механізму взаємодії ЄС та України погодимось із думкою цілої низки дослідників, що важливо сформувати систему правових засобів і заходів, які забезпечували б інтеграційні процеси на кожній зі стадій відповідними способами. Така система заходів має включати: порівняльно-правове дослідження правових систем СС та України, виявлення їх особливостей; визначення оптимальних форм гармонізації, уніфікації і відповідних засобів їх здійснення; визначення видів та рівнів гармонізації й уніфікації та сфер і меж їх застосування; виявлення умов здійснення цих процедур; створення відповідних колізійних механізмів; узгодження термінології; створення словників термінів і понять [10, с. 113].

Державна політика інтеграції України до Свропейського Союзу впливає на всі сфери суспільного життя. На національному рівні поступальний розвиток євроінтеграційних процесів в Україні пов'язаний з адекватним реагуванням у багатьох напрямах на рівні 
реалізації державної політики України відповідно до тактичних завдань держави у сфері європейської та євроатлантичної інтеграції і потребує в найближчій перспективі вирішення низки завдань [7].

План щодо розбудови громадянського суспільства безпосередньо закріплений у положеннях Хартії основних прав Свропейського Союзу, а також у різноманітних напрямах політики ЄС. Інтеграція в Свропейський Союз - це один з основних напрямів міжнародної політики української держави та водночас прагнення вітчизняного суспільства стати вагомою частиною євроспільноти.

Згідно зі статистичними даними Київського міжнародного інституту соціології (КМIC), за інтеграцію України в СС виступають близько половини (від 46\% до 53\%) українців. Однак низка таких подій, як Революція Гідності 2013-2014 років, військово-політичний конфлікт із Російською Федерацією, окупація Криму, нестабільність політики уряду щодо реформ дещо віддаляють членство України в Європі.

Гармонізація систем національного і європейського права не може здійснюватись механічно. По-перше, продовжує діяти принцип державного суверенітету кожної країни. По-друге, різні країни мають багато особливостей, які вони оберігають і не хотіли б втратити в ході інтеграційних процесів. По-третє, ще не вироблено універсальних організаційних механізмів гармонізації відповідних правових систем. По-четверте, мають місце суттєві недоліки в теоретичному вирішенні відповідних проблем, що стримує і їх практичне вирішення [5, с. 146].

Адаптація законодавства України передбачає реформування їі правової системи у напрямі функціональної трансформації та поступове приведення у відповідність до європейських стандартів і охоплює, як було зазначено, приватне, митне, трудове, фінансове, податкове законодавство, законодавство про інтелектуальну власність, охорону праці, охорону життя та здоров'я, навколишнє природне середовище, захист прав споживачів, технічні правила і стандарти, транспорт, а також інші галузі. Термін «адаптація законодавства України до законодавства $Є С$ »е має в Україні ні нормативного, ні наукового обгрунтування; у праві ЄС вживається термін «апроксимація» (зближення). Під апроксимацією законодавства розуміється запровадження в Україні конкретних стандартів, що діють в усіх державах-членах ЄC на підставі «вторинного законодавства» ЄC - директив та регламентів.
Слід зазначити, що саме апроксимація, на наш погляд, зумовлює додаткові труднощі трансформації правового поля в контексті забезпечення прав людини і громадянина, позбавляючи її належної гнучкості. Щодо різновидностей механізмів взаємодії норм міжнародного та національного права, то насамперед виділяють конституційно-правові механізми, міжнародний механізм імплементації, міжнародний організаційно-правовий механізм імплементації, внутрішньодержавний організаційно-правовий механізм тощо. Під конституційно-правовими механізмами взаємодії норм національного і міжнародного права розуміються конституційно-правові норми та інші правові засоби, що забезпечують узгодження міжнародного та національного права [4].

Для збереження позитивних тенденцій та усунення деформацій у правовій системі України важливим кроком для неї на сучасному етапі стало прийняття Концепції правової реформи, яка визначила мету та основні напрями такого реформування, зокрема щодо формування основних структурних частин правової системи України відповідно до сучасних європейських правових стандартів. Вона має містити і вихідні положення правового механізму взаємодії правових систем Ради Європи, Євросоюзу та України, що мають бути частиною її вихідних засад. Основи такої взаємодії мають також визначатися нормами Конституції України та спеціальних законів, зокрема Закону «Про міжнародні договори України» [2].

Для підвищення ефективності правового механізму взаємодії Ради Свропи, Свросоюзу та України важливим є формування системи правових засобів та заходів, які б забезпечували інтеграційні процеси на кожній із стадій відповідними способами. Реалізація цих заходів сприятиме забезпеченню інтеграції правової системи України з європейськими міждержавними правовими системами.

Найбільш важливими сферами взаємодії права $\mathrm{CC}$ і національного права $є$ його безпосередня дія та верховенство стосовно національно-правових норм. Перший принцип (прямої дії) має відношення до імплементації, а другий (верховенства права) - до набуття чинності правом співтовариств. По суті, право $\mathrm{CC}$ являє собою систему норм, що пов'язує всі держави, які завдяки правовому механізму були трансформовані в національні правові системи цих країн [3, с. 92].

Імплементація права СС розуміється як процес транспортування норм права $\mathrm{CC}$, включаючи створення порядку та процедур ïх упровадження в національні правопорядки держав-членів. Це пояснюється тим, 
що такий процес також включає тлумачення, практику застосування, забезпечення дотримання та виконання норм права, які відповідають праву СС, органами державної влади, а також сукупність правових засобів, що використовуються в рамках Європейського Союзу з метою реалізації норм права ЄC [1, c. 19].

Відповідно до ч. 1 ст. 9 Конституції України чинні міжнародні договори, згода на обов'язковість яких надана Верховною Радою України, є частиною національного законодавства України. Це положення розвивається у Рішенні Конституційного Суду України від 9 липня 1998 р. № 12рп/98 у справі за конституційним зверненням Київської міської ради професійних спілок щодо офіційного тлумачення ч. 3 ст. 21 Кодексу законів про працю України (справа про тлумачення терміна «законодавство»), згідно з яким під терміном «законодавство» необхідно розуміти прийняті в межах повноважень і відповідно до Конституції та законів України: закони України, чинні міжнародні договори України, згода на обов'язковість яких надана Верховною Радою України; постанови Верховної Ради України; укази Президента України; декрети і постанови Кабінету Міністрів України [9]

Положення, згідно з яким міжнародні договори є частиною національного законодавства, закріплене також Цивільним кодексом України (ч. 1 ст. 10), Сімейним кодексом України (ч. 1 ст. 13), іншими законодавчими актами України. Згідно зі ст. 3 Кримінального кодексу України законодавство України про кримінальну відповідальність становить Кримінальний кодекс України, який грунтується на Конституції України та загальновизнаних принципах і нормах міжнародного права. Закони України про кримінальну відповідальність мають відповідати положенням, що містяться в чинних міжнародних договорах, згоду на обов'язковість яких надано Верховною Радою України.

Важливим напрямом правової інтеграції України до СС стратегія інтеграції визнала адаптацію законодавства України до законодавства ЄC у сфері забезпечення прав людини. Така адаптація має здійснюватись шляхом зближення із сучасною європейською системою права, вона передбачає реформування правової системи України, поступове приведення її у відповідність до європейських стандартів і охоплює конституційну, митну, трудову, фінансову, приватну та інші галузі, інститути законодавства, визначені Угодою про партнерство та співробітництво.

У напрямі гуманітарного співробітництва ЄС обіцяє підтримку зусиль України щодо виконання їі міжнародних зобов'язань (наприклад, норм і вимог Ради Свропи); налагодження контактів між омбудсменами країн-членів ЄС та України; внеску у розвиток вільних мас-медіа (через співробітництво журналістів та їхніх організацій); поглиблення наукових, студентських, молодіжних обмінів; підтримки програм партнерства між національними, регіональними і місцевими організаціями та іншими інституціями.

При цьому для успішного функціонування демократичної держави відповідальне ставлення суспільства до втілення ухвалених рішень $є$ так само важливим, як і здатність громадськості контролювати владні структури. Кожен член громадянського суспільства мусить відчувати і проявляти свою відповідальність за дотримання основоположних прав і свобод людини, а також за утвердження злагоди і взаємодопомоги в державі. Саме тому успішне функціонування громадянського суспільства можливе лише в умовах правової держави, основною характерною рисою якої є беззаперечне панування закону в усіх сферах суспільно-політичного життя. I в цьому контексті можна говорити про прямий зв'язок між дотриманням законності, суспільним та правовим порядком i розвитком правової держави та громадянського суспільства, що здатне забезпечити захист кожної людини і громадянина [11, c. 337].

Отже, імплементацію норм міжнародного права в національне конституційне законодавство України у контексті більш ефективного забезпечення дотримання прав і свобод людини і громадянина буде методологічно правильним, нормативно доцільним і епістемологічно обгрунтованим розглядати досить широко: по-перше, з урахуванням тих системних управлінських, нормативно-легальних, нормативно-логістичних, нормативнопроцесуальних, суб'єктно-комунікативних і функціонально-результативних імпульсів, які вона виявляє на національне конституційне право; а по-друге, з урахуванням «зворотного» зв'язку і взаємного впливу національного конституційного права держав на загальне міжнародне право. Це особливо виявляється в контексті підвищення аксіологічного (ціннісного) складника імплементації норм міжнародного права в національне конституційне законодавство України, що викликає до життя прояв і функціонування могутнього інтеграційного, кореляційного, гармонізаційного й адаптаційного механізмів.

Особливе значення 3 точки зору перспектив подальшого партнерства між двома сторонами має формування спільної зовнішньої політики та політики безпеки СС 
й оперативного складника - європейської політики в галузі безпеки й оборони. Набуття Свропейським Союзом поряд з економічним також військово-політичного виміру відкриває можливості для взаємодії між Україною і ЄC 3 широкого кола питань світової політики. Євросоюз може стати природним партнером України в пошуках спільних відповідей на нові загрози і виклики європейської та міжнародної безпеки, шляхом вироблення параметрів майбутніх антикризових операцій за участю сил швидкого реагування $Є \mathrm{C}$ [13, c. 95].

Поряд зі спільним урегулюванням криз порядок денний діалогу між Україною і $Є С$ може бути успішно доповнений іншими питаннями, актуальними для безпеки європейського континенту, наприклад проблематикою стратегічної стабільності i протиракетної оборони, питаннями роззброєння та регіональної безпеки. Варто звернути увагу й на думку українського науковця та політика Р.П. Безсмертного, який говорить: «Теза про війну у Європі поки що сприймається і розуміється хіба що тільки на рівні якоїсь частини істеблішменту, окремих осіб. Підтвердженням цьому $є$ й той відомий нідерландський референдум, на якому було висловлено заперечення щодо Асоціації України з СС 6 квітня 2016 р.» [12, с. 17].

\section{Висновки}

Аналізуючи міжнародно-правові фактори впливу на юридичне закріплення й імплементацію прав і свобод людини, у роботі було проаналізовано головні історичні етапи становлення правової співпраці між Україною та СС. Внаслідок цього автором доведено, що євроінтеграція передбачає проведення складних внутрішніх реформ у політичній, соціальній, економічній та правовій сферах, здійснення яких регламентується поетапно Угодою про асоціацію між Україною та ЄС як центральним документом у цьому сегменті політично-правових перетворень. Особливо вагомим у цьому контексті є аксіологічний складник, завдяки якому функціонують інтеграційні та кореляційні механізми узгодження норм українського та міжнародного права.

Адаптація чинного українського законодавства до законодавства $С \mathrm{C}$ - обов'язковий чинник успішної реалізації європейських прагнень України. Розуміння важливості та складності цього процесу, конструктивна співпраця всіх гілок влади, вдале застосування підходів та методів до багатогранності європейського правового поля, а також врахування досвіду асоційованих країн $\mathrm{CC}$ дасть позитивний результат. Європейська інтеграція передбачає цілеспрямоване здійснення урядом та парламентом України цілої низки кроків щодо впровадження європейських стандартів в усіх сферах суспільного і державного життя. Разом із тим варто усвідомлювати, що нинішній стан євроінтеграційних процесів вимагає не тільки чітких, але й більш енергійних кроків керівництвом української держави, які пов'язані перш за все з ефективним проведенням реформ в Україні не в далекій чи ближній перспективі, а вже сьогодні і негайно.

\section{Список використаних джерел:}

1. Брацук І.З. Імплементація права Європейського Союзу в національних правопорядках держав-членів : автореф. дис. на здобуття наук. ступеня канд. юрид. наук. Харків, 2011. 22 с.

2. Закон України «Про міжнародні договори України». Відомості Верховної Ради України (BBP), 2004, № 50, ст. 540.

3. Карпачова Н.I. Стан дотримання Україною європейських стандартів з прав і свобод людини: Спеціальна доповідь Уповноваженого Верховної Ради України з прав людини з нагоди 60-річчя Конвенції про захист прав людини і основоположних свобод. Київ, 2010. 194 с.

4. Луць Л. Конституційно-правовий механізм взаємодії норм міжнародного та національного права: деякі теоретичні аспекти. URL: http://www.lawyer.org.ua.

5. Луць Л. Основні заходи та способи європейської правової інтеграції. Право України. 2002. № 5. C. $146-148$.

6. Луць Л. Формування правового механізму взаємодії України з Радою Європи та Євросоюзом. Віче. 2006. №№ 7/8. С. 54-56.

7. Про затвердження Державної цільової програми інформування громадськості 3 питань європейської інтеграції України на 2008-2011 роки : Постанова Кабінету Міністрів від 2 лип. 2008 р. № 594. Офіи. вісн. Украӥни. 2008. № 49. Ст. 1584 .

8. Рабінович П.М. Європейська конвенція з прав людини: проблеми національної імплементації. Львівська лабораторія прав людини і громадянина. Серія I: Дослідження та реферати. Львів : Астрон, 2002. Вип. 4. С. 12-13.

9. Рішення Конституційного Суду України від 9 липня 1998 р. № 12рп/98 у справі за конституційним зверненням Київської міської ради професійних спілок щодо офіційного тлумачення ч. 3 ст. 21 Кодексу законів про працю України (справа про тлумачення терміна «законодавство»). URL: https://zakon.rada.gov.ua/laws/card/ v012p710-98.

10. Систематизація законодавства України: проблеми та перспективи вдосконалення : монографія. / за ред. Сіренка В.Ф. Київ : Ін-т держави і права iм. В.М. Корецького НАН України, 2003. 220 с.

11. Щекин Г.В. Социальная теория и кадровая политика : монография. Київ : МАУП, 2000.576 с. 
12. Bezsmertnyi R. 'Ukrainsko-rosiiska viina: heopolitychnyi kontekst' [The war between Ukraine and Russia: a geopolitical context]. Mizhnarodni vidnosyny: teoretyko-praktychni aspekty [International Relations: Theory and Practical
Aspects], 2018. Vol. 2, pp. 13-21. DOI: https:// doi.org/10.31866/2616-745x.2.2018.133325.

13. Pierson P. Politics in Time: History, Institutions, and Social Analysis. Princeton, NJ: Princeton University Press. 2004. 248 p.

In the article, becoming and development of international judical collaboration is analysed between Ukraine and EU. A main accent is done on the search of optimal ways of harmonization of the Ukrainian legislation with the legislation of EU in the field of providing of rights and freedoms of man and citizen. It is proved that European integration envisages complex internal reforms in the political, social, economic and legal spheres, which are regulated in stages by the Association Agreement between Ukraine and the EU as the central document in this segment of political and legal transformations. Particularly important in this context is the axiological component, through which the integration and correlation mechanisms of harmonization of norms of Ukrainian and international law function. It is determined that the effectiveness of the norms of international law and the degree of their ideological flexibility, which makes it possible to adapt to the national legislation, in our opinion, depends on the real, full and full use of the entities endowed with their potential. It is emphasized that the main method of harmonization of the national legislation of Ukraine with the legislation of the European Union is indirect harmonization, that is, the adoption of legislative acts should take place in stages, first of all taking into account the interests of our state. It is concluded that the adaptation of the current Ukrainian legislation to the EU legislation is a necessary factor for the successful realization of Ukraine's European aspirations. Understanding the importance and complexity of this process, constructive cooperation of all branches of government, successful application of approaches and methods to the multifaceted European legal field, as well as taking into account the experience of the associated EU countries will have a positive result. European integration involves the deliberate implementation by the Government and Parliament of Ukraine of a number of steps towards the implementation of European standards in all spheres of public and state life. The current state of European integration processes requires not only clear but more vigorous steps by the Ukrainian state leadership, which are primarily concerned with the effective implementation of reforms in Ukraine, not in the distant or near future, but now and immediately.

Key words: international legal norms, rights and freedoms of man, implementation of legal norms, constitutional norms of the legal adjusting. 